\title{
An Approach to Measure Social Capital in Collaborative Networks
}

\author{
António Abreu ${ }^{1,2}$ and Luis M. Camarinha-Matos ${ }^{2}$ \\ ${ }^{1}$ ISEL, Polytechnic Institute of Lisbon, Portugal \\ ${ }^{2}$ CTS - Uninova and Faculdade de Ciências e Tecnologia, Universidade Nova de Lisboa, \\ 2829-516 Caparica, Portugal \\ ajfa@dem.isel.ipl.pt, cam@uninova.pt
}

\begin{abstract}
The characterization and assessment of the social capital of a collaborative network is an important element to help promoting the success of collaboration. The development of indicators of social capital can help enterprise managers not only to analyze and measure their social capital but also to support the decision-making processes. However, models and mechanisms to measure the social capital in collaborative contexts are lacking. Starting with a brief discussion about the nature of social capital and applying some concepts from social networks theory this paper introduces some perspectives and criteria to identify and measure the value of social capital of a member of a Virtual organization Breeding Environment.
\end{abstract}

Keywords: Social Capital, Social Network, Collaborative Networks.

\section{Introduction}

In recent years, the business environments have faced dramatic challenges, which combined with the enabling role of the advances in the information and communication technology, are leading to the emergence of a large variety of collaborative network $(\mathrm{CN})$ forms.

As frequently mentioned by several authors on (e.g. Collaborative Networks), as well as reports from a growing number of practical case studies, when an enterprise is a member of a long-term networked structure, such as a supply chain or a Virtual organizations Breeding Environment (VBE), there is the assumption that such involvement brings valuable (potential) benefits to the involved entities [1, 2], [3]. These benefits include an increase of the "survival capability" in a context of market turbulence, but also the possibility to better achieve common or compatible goals. On the basis of these expectations are, among others, the following factors: joining of complementary skills and capacities, access to new / wider markets and new knowledge, etc [4].

However, it is important to realize that when an enterprise is a member of a longterm networked structure, for instance a Virtual organizations Breeding Environment, its value is not only given by its tangible assets - economic capital (e.g. cash, resources, and goods). In this context, the existence of cooperation agreements, norms, reciprocal relationships, mutual trust, common infrastructures and common 
ontologies, allows members to operate more effectively in the pursuit of their goals. In other words, there is an intuitive assumption that a VBE structure represents a group of organizational entities that have developed intangible assets of "social capital" that bring added value to its members. As a result, in a VBE context the social capital works as a complement to tangible assets, and may have a leveraging effect to increase the value of others assets, and vice versa.

However, although social capital is not a new concept, its definition is not consensual among the various main disciplines that have addressed this topic (e.g. economy, sociology) and therefore several definitions can be found in the literature [5]. This situation results in part from the fact that the social capital needs to be analyzed from a multi-dimensional perspective which has not been considered in previous works. For instance, the diversity of the understandings of social capital varies according to the authors being focused on: the relationships that an actor has with other actors, the structure of relations among actors within a network, or both types of relationships [6].

Social capital metrics tailored to collaborative networks or even an adequate conceptual basis for social capital analysis is not available yet and might be an obstacle for a wider acceptance of this paradigm. According to Stone [7] the tools available for measuring social capital are not enough and further research is required.

Nevertheless, in recent years some preliminary studies have explored the importance of social capital in the context of networked organizations [8], however none of them has proposed methods, approaches or support tools to help managers of enterprises to analyze and measure their social capital in the context of Virtual organizations Breeding Environments.

This paper introduces a brief discussion of the nature of social capital in order to support a model to analyze social capital which is inspired on the Social Networks Analysis area and proposes a set of indicators that are deemed suitable for collaborative networks.

\section{Some Background}

As mentioned above, social capital has been defined according to multiple and separated perspectives or for different purposes. From a sociological perspective, Bourdieu [9] defined social capital as "the aggregate of the actual or potential resources which are linked to possession of a durable network of more or less institutionalized relationships of mutual acquaintance and recognition," while for Portes [10] social capital is "the ability of actors to secure benefits by virtue of membership in social networks or other social structures". On the other hand, from an economic perspective Nahapiet and Ghoshal [11] defined social capital as "the sum of the actual and potential resources embedded within, available through, and derived from the network of relationships possessed by an individual or social unit. Social capital thus comprises both the network and the assets that may be mobilized through that network". For Fukuyama [12] "social capital can be defined simply as the existence of a certain set of informal values or norms shared among members of a group that permit cooperation among them". 
Taking into account the above definitions, it is possible to conclude that social capital is a valuable (intangible) asset which has some typical characteristics of economic capital such as: It can be invested with the expectation of future benefits [13] and is convertible [9]. But, on the other hand, it is different, since its existence lies in the relationships that are established within the network while economic capital can exist at the member level [14]. In other words, social capital cannot be traded by entities on an open market like economic capital, but exclusively within a network [15].

\section{A Model to Analyze Social Capital}

In order to analyze the social capital of each member in a collaborative network, it is necessary to develop a model that supports the analysis of the relationships among members and the assets that may be accessed through the network of contacts.

Therefore, as a first approach, these relationships can be modeled using graphs, as illustrated in Fig. 1. The proposed model [16] considers elementary-maps and aggregate-maps. The elementary maps are:

- Map of business contacts - a graph showing the network of formal relationships with the purpose to provide services or goods to satisfy a request among members belonging to the network. In this case, the link's width represents the level of relationship between two enterprises in a defined time interval, and its value is given by the following equation:

$$
\begin{gathered}
L R_{i j}=w_{1} \times S R F C_{i j} \times S R I C_{i j}+w_{2} \times P R F C_{i j} \times P R I C \times V S_{i j} \\
\sum_{j=1}^{2} w_{j}=1 \text { and } w_{j}>0
\end{gathered}
$$

Where:

$L R_{i j}$ - Level of relationship between enterprise $\mathrm{i}$ and enterprise $\mathrm{j}$, in a defined time interval. It has a value over the interval $[0,+\infty[$.

$S R F C_{i j}$ - Frequency of contacts between enterprise $\mathrm{i}$ and enterprise $\mathrm{j}$, based on subordinate relation, in a defined time interval. It has a value over the interval $[0,+\infty[$.

$S R I C_{i j}$ - Intensity of contacts between enterprise $\mathrm{i}$ and enterprise $\mathrm{j}$, based on subordinate relation, in a defined time interval. It has a value over the interval $[0,1]$.

$P R F C_{i j}$ - Frequency of contacts between enterprise $\mathrm{i}$ and enterprise $\mathrm{j}$, based on peer relation, in a defined time interval. It has a value over the interval $[0,+\infty[$. $P R I C_{i j}$ - Intensity of contacts between enterprise $\mathrm{i}$ and enterprise $\mathrm{j}$, based on peer relation. It has a value over the interval $[0,1]$.

$V S_{i j}$ - Value systems alignment between enterprise $\mathrm{i}$ and enterprise $\mathrm{j}$, in a defined time interval. It has a value over the interval $[0,1]$. 
However, the main difficulty is naturally the determination of each of the five components mentioned above. To collect and record those values without being intrusive in the network members" "life" requires further research and development.

- Map of enterprises' assets - a graph that shows the assets held by each enterprise and how they are shared. In this case, there are two sets of nodes: enterprises and assets. The nodes are connected by ownership/access relations.

The aggregate-maps show how an enterprise may have access to assets held by another enterprise. It results from the aggregation of the map of business contacts and the map of enterprises' assets. Based on this map, it is now possible to analyze the social capital of each enterprise through a visual representation of the assets that are held by an enterprise.

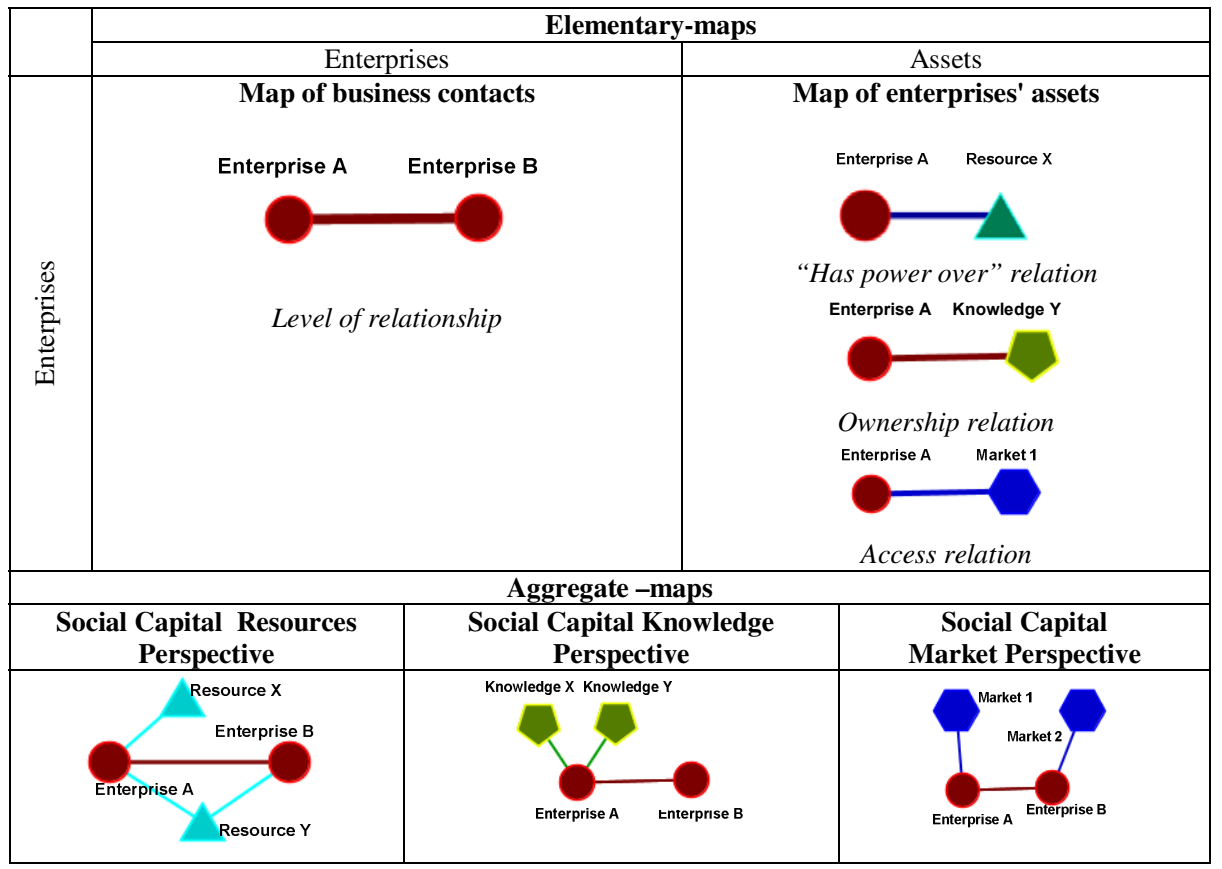

Fig. 1. Simple model to analyze Social Capital in CNs

Combining these concepts with elements from the Social Network Analysis area, a set of basic indicators tailored to collaborative networks is proposed as shown in Table 1 and Table 2. Table 1 includes a list of indicators to analyze in detail the level of relationships between enterprises and Table 2 shows a set of indicators to evaluate the level of expertise of an enterprise and how the assets are shared in the network. 
Table 1. Indicators for relationship analysis

\begin{tabular}{|c|c|c|}
\hline Indicator & Short Description & Expression \\
\hline $\begin{array}{c}\text { Individual } \\
\text { Business } \\
\text { Contacts } \\
\left(\text { IBC }_{\mathrm{i}}\right)\end{array}$ & $\begin{array}{l}\text { Definition } \\
\text { This indicator measures the number of distinct business contacts / } \\
\text { "collaborative processes" that an enterprise has established with } \\
\text { other enterprises. In terms of social network analysis, it corresponds } \\
\text { to the node degree. } \\
\text { Potential Use } \\
\text { - Assessment of the level of collaboration } \\
\text { - Assessment the prestige/popularity of an enterprise }\end{array}$ & $\begin{array}{l}\mathrm{IBC}_{\mathrm{i}}=\begin{array}{c}\text { Number } \\
\text { contacts connected }\end{array} \\
\text { node } e_{i} \\
e_{i} \text { - enterprise } \mathrm{i}\end{array}$ \\
\hline $\begin{array}{c}\text { Apparent } \\
\text { Individual } \\
\text { Business } \\
\text { Contacts Index } \\
\left.(\text { AIBCI })_{i}\right)\end{array}$ & $\begin{array}{l}\text { Definition } \\
\text { This index represents the ratio between the individual business } \\
\text { contacts of an enterprise and the total of enterprises involved in the } \\
\text { network. } \\
\text { Potential Use } \\
\text { This index gives an apparent and simple to compute measure of } \\
\text { accessibility of an enterprise to the assets that can be mobilized } \\
\text { through the network. An enterprise with an AIBCI close to zero } \\
\text { means that such enterprise might not have access to the assets } \\
\text { available within the network. }\end{array}$ & $\begin{array}{l}\qquad A I B C I_{i}=\frac{I B C_{i}}{N} \\
\mathrm{~N}-\text { Number of nodes } \\
\text { involved in the network }\end{array}$ \\
\hline $\begin{array}{c}\text { Individual } \\
\text { Business } \\
\text { Contacts Index } \\
\quad\left(\text { IBCI }_{\mathbf{i}}\right)\end{array}$ & $\begin{array}{l}\text { Definition } \\
\text { This index measures the ratio between the individual business } \\
\text { contacts of an enterprise and the sum of the individual business } \\
\text { contacts of all enterprises involved in the network. } \\
\text { Potential Use } \\
\text { - Normalization of the level of involvement of an enterprise in } \\
\text { relation to other members of the network. } \\
\text { - Benchmarking with enterprises involved in other networks. }\end{array}$ & $\begin{array}{l}I B C I_{i}=\frac{I B C_{i}}{\sum_{j=1}^{N} I B C_{j}} \\
\begin{array}{l}\mathrm{N}-\text { Number of nodes } \\
\text { involved in the network }\end{array}\end{array}$ \\
\hline $\begin{array}{c}\text { Individual Level } \\
\text { of Relationship } \\
\qquad\left(\mathbf{I L R}_{\mathbf{i}}\right)\end{array}$ & $\begin{array}{l}\text { Definition } \\
\text { The sum of the level of the relationships that an enterprise achieved } \\
\text { as a result of its performance in collaborative process. } \\
\text { Potential Use } \\
\text { - Evaluate the behaviour of an enterprise. An enterprise with a low } \\
\text { level of ILR means that such enterprise might exhibit a non- } \\
\text { collaborative behaviour. } \\
\text { - Evaluate the prominence level of an enterprise, assuming that } \\
\text { prominent enterprises are those that are extensively involved in } \\
\text { relationships with other enterprises. }\end{array}$ & $\begin{array}{l}I L R_{i}=\sum_{j=1}^{N} L R_{i j} \\
L R_{i j}-\text { Level of } \\
\text { relationship between actor } \\
\text { i and actor } \mathrm{j} \text {. } \\
\mathrm{N}-\text { Number of nodes } \\
\text { involved in the network }\end{array}$ \\
\hline $\begin{array}{l}\text { Individual Level } \\
\text { Relationship } \\
\text { index } \\
\left(\text { ILRI }_{i}\right)\end{array}$ & $\begin{array}{l}\text { Definition } \\
\text { This index represents the ratio between the individual level of } \\
\text { relationship of an enterprise and the sum of the individual level of } \\
\text { relationship of all enterprises involved in the network. } \\
\text { Potential Use } \\
\text { - Normalization of the level of relationships of an enterprise in } \\
\text { relation to other members of the network. } \\
\text { - Benchmarking with enterprises involved in other networks. }\end{array}$ & $\begin{array}{l}I L R I_{i}=\frac{I L R_{i}}{\sum_{j=1}^{N} I L R_{j}} \\
\begin{array}{l}\mathrm{N}-\text { Number of nodes } \\
\text { involved in the network }\end{array}\end{array}$ \\
\hline $\begin{array}{l}\text { Individual Level } \\
\text { of Accessibility } \\
\qquad\left(\mathbf{I L A}_{\mathbf{i}}\right)\end{array}$ & $\begin{array}{l}\text { Definition } \\
\text { This indicator measures for each enterprise the ratio between the } \\
\text { individual level of relationship and the individual business contacts. } \\
\text { Potential Use } \\
\text { This indicator measures the level of accessibility or ability of an } \\
\text { enterprise to access the assets that can be mobilized through the } \\
\text { network. }\end{array}$ & $I L A_{i}=\frac{I L R_{i}}{I B C_{i}}$ \\
\hline $\begin{array}{c}\text { Individual } \\
\text { Accessibility } \\
\text { Index } \\
\left(\mathbf{I A} \mathbf{I}_{\mathrm{i}}\right)\end{array}$ & $\begin{array}{l}\text { Definition } \\
\text { This indicator measures, for each enterprise, the ratio between the } \\
\text { individual level of accessibility of an enterprise and the sum of the } \\
\text { individual levels of accessibility of all enterprises involved in the } \\
\text { network. } \\
\text { Potential Use } \\
\text { - Normalization of the level of accessibility of an enterprise in } \\
\text { relation to other members of the network. } \\
\text { - Benchmarking with enterprises involved in other networks. }\end{array}$ & $\begin{array}{l}I A I_{i}=\frac{I L A_{i}}{\sum_{j=1}^{N} I L A_{j}} \\
\mathrm{~N}-\text { Number of nodes } \\
\text { involved in the network }\end{array}$ \\
\hline
\end{tabular}


Table 2. Indicators for assets analysis

\begin{tabular}{|c|c|c|}
\hline Indicator & Short Description & Expression \\
\hline $\begin{array}{c}\text { Total of Assets } \\
\text { (M) }\end{array}$ & $\begin{array}{l}\text { Definition } \\
\text { This indicator counts the number of distinct assets held by the } \\
\text { network. } \\
\text { Potential Use } \\
\text { This indicator measures the level of versatility/polyvalence of } \\
\text { the network. }\end{array}$ & $\begin{array}{l}\qquad M=\sum_{j=1}^{A} m_{j} \\
\begin{array}{l}\text { A }- \text { Number of distinct } \\
\text { assets involved in the } \\
\text { network } \\
\mathrm{m}_{\mathrm{j}} \text { - asset } \mathrm{j}\end{array}\end{array}$ \\
\hline $\begin{array}{c}\text { Total of } \\
\text { enterprise } \\
\text { Owned Assets } \\
\left(\mathrm{TOA}_{\mathbf{i}}\right)\end{array}$ & $\begin{array}{l}\text { Definition } \\
\text { This indicator measures the number of distinct assets held by an } \\
\text { enterprise. In terms of social network analysis, it corresponds to } \\
\text { the enterprise's node degree. } \\
\text { Potential Use } \\
\text { This indicator measures the level of expertise or capacity of an } \\
\text { enterprise. }\end{array}$ & $\begin{array}{c}\mathrm{TOA}_{\mathrm{i}}=\text { Number of } \\
\text { ownership relations } \\
\text { connected to enterprise } e_{i}\end{array}$ \\
\hline $\begin{array}{c}\text { Apparent } \\
\text { Owned Assets } \\
\text { Index } \\
\left(\text { AOAI }_{\mathbf{i}}\right)\end{array}$ & $\begin{array}{l}\text { Definition } \\
\text { This index represents the ratio between the number of assets that } \\
\text { belong to an enterprise and the number of the assets that can be } \\
\text { mobilized through the network. } \\
\text { Potential Use } \\
\text { This indicator measures the potential level of dependence that } \\
\text { an enterprise might have in relation to the assets that can be } \\
\text { mobilized through the network. An enterprise with an AOAI } \\
\text { close to one means that this enterprise is the owner of nearly all } \\
\text { assets available within the network. }\end{array}$ & $\begin{array}{l}\text { M - Number of assets held } \\
\text { by the network }\end{array}$ \\
\hline $\begin{array}{l}\text { Owned Assets } \\
\text { Index } \\
\left(\mathbf{O A I}_{\mathrm{i}}\right)\end{array}$ & $\begin{array}{l}\text { Definition } \\
\text { This index represents the ratio between the number of assets that } \\
\text { belong to an enterprise and the sum of the number of distinct } \\
\text { assets held by all enterprises involved in the network. } \\
\text { Potential Use } \\
\text { - Normalization of the number of assets held by an enterprise } \\
\text { in relation to other members of the network. } \\
\text { - Benchmarking with enterprises involved in other networks. }\end{array}$ & $\begin{array}{l}\qquad O A I_{i}=\frac{T O A_{i}}{\sum_{j=1}^{N} T O A_{j}} \\
\begin{array}{l}\mathrm{N}-\text { Number of enterprises } \\
\text { involved in the network }\end{array}\end{array}$ \\
\hline $\begin{array}{c}\text { Partial Owned } \\
\text { Assets } \\
\left(\text { POA }_{\text {ik }}\right)\end{array}$ & $\begin{array}{l}\text { Definition } \\
\text { This indicator accounts for the number of distinct assets held by } \\
\text { an enterprise according to perspective } \mathrm{k} \text { for instance: innovation, } \\
\text { capacity and market. In terms of social network analysis, it } \\
\text { corresponds to the enterprise's node degree for perspective k. } \\
\text { Potential Use } \\
\text { This indicator measures the level of expertise of each enterprise } \\
\text { according to perspective k. }\end{array}$ & $\begin{array}{c}\mathrm{POA}_{\mathrm{ik}}=\text { number of } \\
\text { ownership relations } \\
\text { according to perspective } k \\
\text { connected to enterprise } e_{i}\end{array}$ \\
\hline $\begin{array}{l}\text { Apparent } \\
\text { Partial } \\
\text { Specialization } \\
\text { Index } \\
\left(\text { APSI }_{\text {ik }}\right)\end{array}$ & $\begin{array}{l}\text { Definition } \\
\text { This index measures the ratio between the number of assets } \\
\text { according to perspective } k \text { that belong to an enterprise and the } \\
\text { total of the assets according to perspective } k \text { that can be } \\
\text { mobilized through the network. } \\
\text { Potential Use } \\
\text { This indicator gives an indication of the level of specialization } \\
\text { of an enterprise according to perspective } \mathrm{k} \text {. An enterprise with } \\
\text { an APSI close to one means that such enterprise within the } \\
\text { network is specialized in this perspective } k \text {. }\end{array}$ & $\begin{array}{l}\qquad A P S I_{i k}=\frac{P O A_{i k}}{M_{k}} \\
\mathrm{M}_{\mathrm{k}}-\text { Number of assets held } \\
\text { by the network according to } \\
\text { perspective } k \text {. }\end{array}$ \\
\hline $\begin{array}{l}\text { Partial } \\
\text { Specialization } \\
\text { Index } \\
\left(\text { PSI }_{\text {ik }}\right)\end{array}$ & $\begin{array}{l}\text { Definition } \\
\text { This indicator measures, for each enterprise, the ratio between } \\
\text { the Apparent Partial Specialization of an enterprise and the sum } \\
\text { of the Apparent Partial Specialization of all enterprises involved } \\
\text { in the network. } \\
\text { Potential Use } \\
\text { - Normalization of the level of specialization of an enterprise } \\
\text { according to perspective } k \text { in relation to other members of the } \\
\text { network. } \\
\text { - Benchmarking with enterprises involved in other networks. }\end{array}$ & $\begin{array}{l}P S I_{i k}=\frac{A P S I_{i k}}{\sum_{j=1}^{N} A P S I_{j k}} \\
\begin{array}{l}\mathrm{N}-\text { Number of enterprises } \\
\text { involved in the network }\end{array}\end{array}$ \\
\hline
\end{tabular}


Table 2. (Continued)

\begin{tabular}{|c|c|c|}
\hline $\begin{array}{c}\text { Assets } \\
\text { Abundance } \\
\qquad\left(\mathbf{A} \mathbf{A}_{\mathbf{i}}\right)\end{array}$ & $\begin{array}{l}\text { Definition } \\
\text { This indicator counts the number of distinct ownership relations } \\
\text { of an asset. In terms of social network analysis, it corresponds to } \\
\text { the node's degree. } \\
\text { Potential Use } \\
\text { This indicator measures the level of abundance of an asset inside } \\
\text { the network. An asset with an AA close to one means that it is } \\
\text { exclusive because it is owned by few enterprises of the network. }\end{array}$ & $\begin{array}{l}\mathrm{AA}_{\mathrm{i}}=\text { Number of ownership } \\
\text { relations connected to asset } \\
\qquad a_{i}\end{array}$ \\
\hline $\begin{array}{l}\text { Apparent Assets } \\
\text { Exclusivity } \\
\text { Index } \\
\left(\text { AAEI }_{\mathbf{i}}\right)\end{array}$ & $\begin{array}{l}\text { Definition } \\
\text { This index measures the ratio between the level of proliferation } \\
\text { of an asset and the number of enterprises involved in the } \\
\text { network. } \\
\text { Potential Use } \\
\text { This index gives a simple to compute measure of exclusivity of } \\
\text { an asset. An asset with an AAEI near to zero means that such } \\
\text { asset belongs to few enterprises. On the other hand, an asset } \\
\text { with an AAEI close to one means that such asset is owned by all } \\
\text { enterprises in the network. }\end{array}$ & $\begin{array}{l}\qquad A A E I_{i}=\frac{A A_{i}}{N} \\
\text { N-Number of enterprises } \\
\text { involved in the network }\end{array}$ \\
\hline $\begin{array}{l}\text { Assets } \\
\text { Exclusivity } \\
\text { Index } \\
\left(\mathbf{A E I}_{\mathbf{i}}\right)\end{array}$ & $\begin{array}{l}\text { Definition } \\
\text { This index measures the ratio between the level of proliferation } \\
\text { of an asset and the sum of the number of distinct assets held by } \\
\text { all enterprises involved in the network } \\
\text { Potential Use } \\
\text { - Normalization of the level of exclusivity of an asset in the } \\
\text { network. } \\
\text { - Benchmarking with other networks. }\end{array}$ & $\begin{array}{l}\qquad A E I_{i}=\frac{A A_{i}}{\sum_{j=1}^{M} A A_{j}} \\
\begin{array}{l}\text { M - Number of assets held } \\
\text { by the network }\end{array}\end{array}$ \\
\hline $\begin{array}{l}\text { Partial Owned } \\
\text { Assets Worth } \\
\left.\text { (POAW }_{\text {ik }}\right)\end{array}$ & $\begin{array}{l}\text { Definition } \\
\text { The sum of the worth of the assets that are held by an enterprise } \\
\text { according to perspective } \mathrm{k} \text {. } \\
\text { Potential Use } \\
\text { The purpose of this indicator is to measure the worth of the } \\
\text { assets that are held by an enterprise according to perspective } \mathrm{k} \text {. }\end{array}$ & $\begin{array}{l}\left(P O A W_{i k}\right)=\sum_{m=1}^{M} v_{A m, i, k} \\
\mathrm{M}-\text { Number of assets held } \\
\text { by the network } \\
v_{A m, i, k}-\text { Value assigned } \\
\text { to asset } A m \text { held by } \\
\text { enterprise } i \text { according to } \\
\text { perspective k. }\end{array}$ \\
\hline $\begin{array}{l}\text { Total of Owned } \\
\text { Assets Worth } \\
\left.\text { TOAW }_{\mathrm{i}}\right)\end{array}$ & $\begin{array}{l}\text { Definition } \\
\text { The sum of the worth of the assets that are held by an enterprise. } \\
\text { Potential Use } \\
\text { The purpose of this indicator is to measure the total worth of the } \\
\text { assets that are held by an enterprise. }\end{array}$ & $\begin{array}{l}\left(T O A W_{i}\right)=\sum_{k=1}^{K} P O A W_{i k} \\
\mathrm{~K}-\text { number of distinct } \\
\text { perspectives }\end{array}$ \\
\hline $\begin{array}{l}\text { Partial Owned } \\
\text { Assets Worth } \\
\quad \text { Index } \\
\text { (POAWI } \\
\text { Po })\end{array}$ & $\begin{array}{l}\text { Definition } \\
\text { This index measures, for each enterprise, the ratio between the } \\
\text { worth of the assets that are held by an enterprise according to } \\
\text { perspective } \mathrm{k} \text {, and the sum of the worth of the assets that are } \\
\text { held by all enterprises involved in the network according to } \\
\text { perspective k. } \\
\text { Potential Use } \\
\text { - Normalization of the assets worth of an enterprise according } \\
\text { to perspective } k \text { in relation to other members of the network. } \\
\text { - Benchmarking with enterprises involved in other networks. }\end{array}$ & $\begin{array}{l}P O A W_{i k}=\frac{P O A W_{i k}}{\sum_{i=1}^{N} P O A W_{i k}} \\
\begin{array}{l}\mathrm{N}-\text { Number of enterprises } \\
\text { involved in the network }\end{array}\end{array}$ \\
\hline $\begin{array}{l}\text { Total of Owned } \\
\text { Assets Worth } \\
\text { Index } \\
\quad(\text { TOAWI })\end{array}$ & $\begin{array}{l}\text { Definition } \\
\text { This index measures, for each enterprise, the ratio between the } \\
\text { worth of the assets that are held by an enterprise, and the sum of } \\
\text { the worth of the assets that are held by all enterprises involved } \\
\text { in the network. } \\
\text { Potential Use } \\
\text { - Normalization of the assets worth of an enterprise in relation } \\
\text { to other members of the network. } \\
\text { - Benchmarking with enterprises involved in other networks. }\end{array}$ & $\begin{array}{l}T O A W_{i}=\frac{T O A W_{i}}{\sum_{i=1}^{N} T O A W_{i}} \\
\begin{array}{l}\mathrm{N}-\text { Number of enterprises } \\
\text { involved in the network }\end{array}\end{array}$ \\
\hline
\end{tabular}




\section{Example Application}

In order to analyze and measure the social capital of members of a collaborative network, the following example illustrates how the proposed indicators can be used.

For this scenario, the existence of a VBE is considered, which contains seven enterprises identified as E1 to E7. Let us suppose that at the VBE management level there are records of the enterprises' past involvement in collaboration activities, which makes it possible to quantify the level of relationships between enterprises $\left(L R_{i j}\right)$ as illustrated in Table 3.A, and there are also records of the type of assets, value of each one of those assets that can be mobilized through the network, and how the assets are held by each enterprise, as illustrated in Table 3.B.

Table 3. a) Record of the level of relationships. b) Record of the assets worth

\begin{tabular}{|c|c|c|c|c|c|c|c|c|c|c|c|}
\hline & E1 & E2 & E3 & $E 4$ & E5 & E6 & E7 & $\Delta$ & & & \\
\hline E1 & 0 & 0 & 0 & 0 & 0 & 0 & 30 & & & & \\
\hline E2 & 0 & 0 & 90 & 50 & 50 & 50 & 0 & & & & \\
\hline E3 & 0 & 90 & 0 & 0 & 0 & 90 & 0 & & & & \\
\hline E4 & 0 & 50 & 0 & 0 & 20 & 0 & 0 & & & & \\
\hline E5 & 0 & 50 & 0 & 20 & 0 & 10 & 10 & & & & \\
\hline E6 & 0 & 50 & 90 & 0 & 10 & 0 & 0 & & & & \\
\hline \multirow[t]{3}{*}{ E7 } & 30 & 0 & 0 & 0 & 10 & 0 & 0 & & & $R$ & \\
\hline & \multicolumn{4}{|c|}{ Knowledge } & \multicolumn{3}{|c|}{ Market } & \multicolumn{4}{|c|}{ Resources } \\
\hline & K1 & $\mathrm{K} 2$ & K3 & K4 & M1 & M2 & M3 & R1 & R2 & R3 & R4 \\
\hline E1 & 10 & 0 & 0 & 0 & 20 & 0 & 0 & 0 & 0 & 0 & 0 \\
\hline E2 & 0 & 20 & 20 & 0 & 20 & 0 & 0 & 30 & 0 & 0 & 0 \\
\hline E3 & 10 & 20 & 20 & 0 & 20 & 0 & 0 & 30 & 0 & 0 & 0 \\
\hline E4 & 0 & 0 & 0 & 0 & 0 & 10 & 0 & 0 & 40 & 0 & 0 \\
\hline E5 & 0 & 20 & 20 & 0 & 0 & 10 & 0 & 0 & 0 & 50 & 0 \\
\hline E6 & 10 & 0 & 0 & 0 & 0 & 10 & 0 & 0 & 0 & 50 & 0 \\
\hline E7 & 0 & 0 & 0 & 50 & 0 & 10 & 50 & 0 & 40 & 0 & 50 \\
\hline
\end{tabular}

Table 4. Indicators for relationships analysis

\begin{tabular}{|r|r|r|r|r|r|r|r|}
\hline & IBC & AIBCI & IBCI & ILR & ILRI & ILA & ILAI \\
\hline E1 & 1 & $14 \%$ & $6 \%$ & 30 & $4 \%$ & 30 & $10 \%$ \\
\hline E2 & 4 & $57 \%$ & $22 \%$ & 240 & $30 \%$ & 60 & $20 \%$ \\
\hline E3 & 2 & $29 \%$ & $11 \%$ & 180 & $23 \%$ & 90 & $29 \%$ \\
\hline E4 & 2 & $29 \%$ & $11 \%$ & 70 & $9 \%$ & 35 & $11 \%$ \\
\hline E5 & 4 & $57 \%$ & $22 \%$ & 90 & $11 \%$ & 23 & $7 \%$ \\
\hline E6 & 3 & $43 \%$ & $17 \%$ & 150 & $19 \%$ & 50 & $16 \%$ \\
\hline E7 & 2 & $29 \%$ & $11 \%$ & 40 & $5 \%$ & 20 & $7 \%$ \\
\hline
\end{tabular}

Based on the data of the level of relationships presented in Table 3.A, and applying the equations defined in Table 1, the Table 4 shows some examples of indicators for this network.

Analysing the value of the indicators in Table 4, it is possible to verify, for instance, according to the apparent individual business contact index (AIBCI), that enterprises E2 and E5 are the most involved in collaboration with other enterprises and both have relationships with $57 \%$ of the members of this network. However, in terms of individual level of accessibility (ILA), the highest value belongs to enterprise E3. 
Table 5. Indicators for assets analysis

\begin{tabular}{|c|c|c|c|c|c|c|c|c|c|c|c|}
\hline \multirow{2}{*}{$\mathbf{A}$} & \multicolumn{5}{|c|}{ Knowledge } & $\mathbf{D}$ & \multicolumn{5}{|c|}{ Global } \\
\hline & POA & APSI & PSI & POAW & POAWI & D & TOA & AOAI & OAI & TOAW & TOAWI \\
\hline E1 & 1 & $25 \%$ & $10 \%$ & 10 & $5 \%$ & E1 & 2 & $18 \%$ & $8 \%$ & 30 & $5 \%$ \\
\hline E2 & 2 & $50 \%$ & $20 \%$ & 40 & $20 \%$ & E2 & 4 & $16 \%$ & $16 \%$ & 90 & $14 \%$ \\
\hline E3 & 3 & $75 \%$ & $30 \%$ & 50 & $25 \%$ & E3 & 5 & $20 \%$ & $20 \%$ & 100 & $16 \%$ \\
\hline E4 & 0 & $0 \%$ & $0 \%$ & 0 & $0 \%$ & E4 & 2 & $8 \%$ & $8 \%$ & 50 & $8 \%$ \\
\hline E5 & 2 & $50 \%$ & $20 \%$ & 40 & $20 \%$ & E5 & 4 & $16 \%$ & $16 \%$ & 100 & $16 \%$ \\
\hline E6 & 1 & $25 \%$ & $10 \%$ & 10 & $5 \%$ & E6 & 3 & $12 \%$ & $12 \%$ & 70 & $11 \%$ \\
\hline E7 & 1 & $25 \%$ & $10 \%$ & 50 & $25 \%$ & E7 & 5 & $20 \%$ & $20 \%$ & 190 & $30 \%$ \\
\hline Total & & 4 & & 200 & & & & & & & \\
\hline \multirow{2}{*}{ B } & \multicolumn{5}{|c|}{ Market } & & \multirow{2}{*}{$\bar{E}$} & \multicolumn{3}{|c|}{ Assets } & \\
\hline & POA & APSI & $\mathrm{PSI}$ & POAW & POAWI & & & AA & AAEI & AEI & \\
\hline E1 & 1 & $33 \%$ & $13 \%$ & 20 & $14 \%$ & & K1 & 3 & $43 \%$ & $12 \%$ & \\
\hline E2 & 1 & $33 \%$ & $13 \%$ & 20 & $14 \%$ & & $k 2$ & 3 & $43 \%$ & $12 \%$ & \\
\hline E3 & 1 & $33 \%$ & $13 \%$ & 20 & $14 \%$ & & K3 & 3 & $43 \%$ & $12 \%$ & \\
\hline E4 & 1 & $33 \%$ & $13 \%$ & 10 & $7 \%$ & & K4 & 1 & $14 \%$ & $4 \%$ & \\
\hline E5 & 1 & $33 \%$ & $13 \%$ & 10 & $7 \%$ & & M1 & 3 & $43 \%$ & $12 \%$ & \\
\hline E6 & 1 & $33 \%$ & $13 \%$ & 10 & $7 \%$ & & M2 & 4 & $57 \%$ & $16 \%$ & \\
\hline E7 & 2 & $67 \%$ & $25 \%$ & 50 & $36 \%$ & & M3 & $\frac{4}{1}$ & $14 \%$ & $4 \%$ & \\
\hline \multirow[t]{3}{*}{ Total } & & 3 & & 140 & & & R1 & 2 & $29 \%$ & $8 \%$ & \\
\hline & \multicolumn{5}{|c|}{ Resources } & & R2 & 2 & $29 \%$ & $8 \%$ & \\
\hline & POA & APSI & PSI & POAW & POAWI & & R3 & 2 & $29 \%$ & $8 \%$ & \\
\hline E1 & 0 & $0 \%$ & $0 \%$ & 0 & 0 & & R4 & 1 & $14 \%$ & $4 \%$ & \\
\hline E2 & 1 & $25 \%$ & $14 \%$ & 30 & $10 \%$ & & & & & & \\
\hline E3 & 1 & $25 \%$ & $14 \%$ & 30 & $10 \%$ & & & & & & \\
\hline E4 & 1 & $25 \%$ & $14 \%$ & 40 & $14 \%$ & & & & & & \\
\hline E5 & 1 & $25 \%$ & $14 \%$ & 50 & $17 \%$ & & & & & & \\
\hline E6 & 1 & $25 \%$ & $14 \%$ & 50 & $17 \%$ & & & & & & \\
\hline E7 & 2 & $50 \%$ & $29 \%$ & 90 & $31 \%$ & & & & & & \\
\hline Total & & 4 & & 290 & & & & & & & \\
\hline
\end{tabular}

Taking into account this example, let us now suppose that enterprises E3 and E5 need to have access to some assets in order to accomplish a business opportunity. In this case, if the assets are held by enterprises with which both have business contacts, the enterprise that has more chances of being successful is the enterprise E3.

Based on the data on the type of assets, value of each asset, and how the assets are held by each member, presented in Table 3.B, and applying the equations defined in Table 2, the Table 5 shows some examples of indicators to evaluate the level of expertise of an enterprise and how the assets might be shared within this network.

Based on these data, it is possible to verify, for instance, that according to the knowledge perspective (see Table 5.A), in terms of assets worth (see POAW), enterprises E3 and E7 have identical values despite the enterprise E3 having more assets than the enterprise E7 (see POA).

Using graphs to analyze social capital. The adoption of quantified indicators combined with a graphical visualization provides a tool to analyse in detail the 'substructures' that may be present in a collaborative network. Divisions of members into cliques, i.e. sub-structures of a network in which the members are more closely and intensely linked to one another than they are to other members of the network, can be important to understand how social capital flows within the network.

On the other hand, at micro level the knowledge of how a member is embedded in a sub-structure within a network may be important to understand how it can increase its social capital. For instance, some members can act as 'bridges' between groups. In Fig. 2, the enterprise E5 acts as a bridge between the sub-structure made by enterprise E7 and enterprise E1 and the other enterprises of the network. Furthermore, the node's size in Fig. 2 represents the proportion of assets that are held by each 
enterprise, and the link's width represents the value of the level of relationship between enterprises. Hence, the enterprises that hold more assets are enterprises E7 and E3. On the other hand, if we look at the links between enterprises, we can easily identify a clique, for instance, among enterprises E2, E3 and E6 with a high level of accessibility among them.

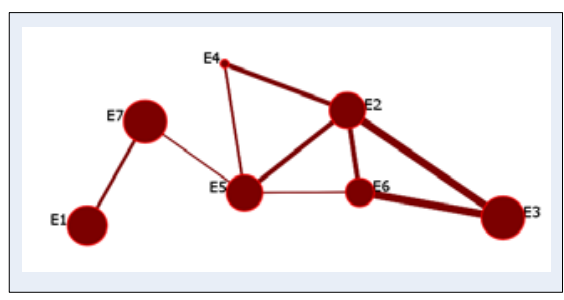

Fig. 2. Owner Assets Index

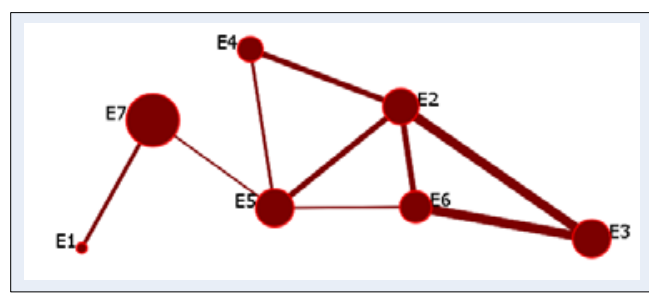

Fig. 3. Total of Owner Assets Worth

The nodes' size in Fig. 3 represents the worth of the assets hold by each enterprise, and the link's width represents the value of the level of the relationship between them. Hence, in this network, the enterprise that holds more social capital is enterprise E7. However, as enterprise E7 has a low level of accessibility, the links around enterprise E7 are narrow, which can act as an obstacle to increase the social capital of this network.

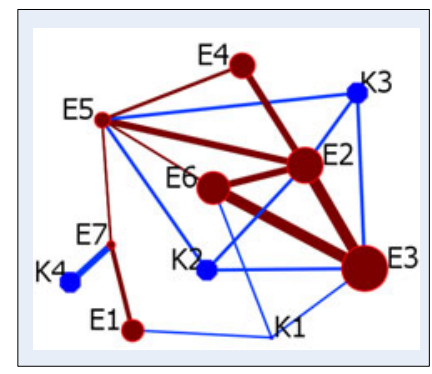

Fig. 4. Individual Level of Accessibility and assets worth

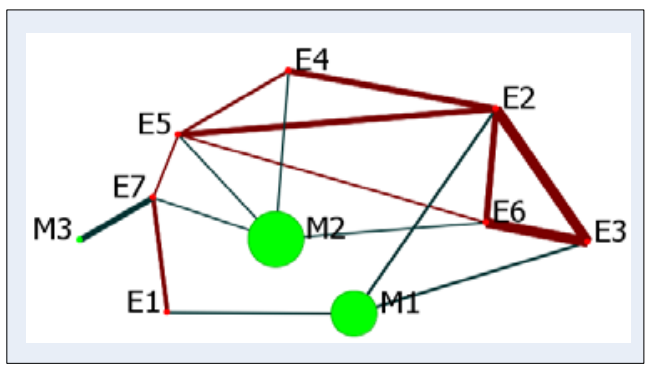

Fig. 5. Apparent Assets Exclusivity index and "level of health" of the relationships

Fig. 4 illustrates the advantage of this model in the use of multiple indicators. In this example, the nodes' size of the enterprises represents the individual level of accessibility (ILA) of each enterprise. The link's width between enterprises represents the value of the level of relationship among them, and the link's width between an enterprise and an asset represents the worth of that asset. In this case, the nodes' size of the assets is identical because they have no associated metrics.

Hence, according to the knowledge perspective, it is possible to verify that the most valuable asset is $\mathrm{K} 4$, and it is an exclusive asset that is hold by enterprise E7. Furthermore, the enterprise E7 has the lowest level of accessibility. In this context, despite the asset $\mathrm{K} 4$ belongs to the bag of network's assets, only a small group of enterprises is likely to be successful in accessing to this asset through the network of 
business contacts. For instance, in this case, although enterprise E3 holds the highest value in terms of individual level of accessibility, based on this analysis it hardly can access to the asset $\mathrm{K} 4$.

On the other hand, Fig. 5 illustrates an example of analysis of the abundance of the assets by the members of the network. In this case, the nodes' size of the assets represents the level of abundance of each asset in this network. The link's width between enterprises represents the value of the level of relationship among them, and the link's width between an enterprise and an asset represents the worth of that asset. The nodes' size of the enterprises is identical because they have no associated metrics. In this case, the most common asset is the asset M2, and the asset M3 is the most valuable one, which is also an exclusive asset that is hold by enterprise E7.

\section{Conclusions}

Reaching a better characterization and understanding of the role of social capital in collaborative processes is an important element for a better understanding of the behavioral aspects in the collaborative networks paradigm in its various manifestation forms.

The definition of a set of indicators to capture and measure the social capital can be a useful instrument to support the promotion of collaborative behaviours, and for a VBE member a way to extract the advantages of belonging to a network.

Using simple calculations as illustrated above, it is possible to extract some indicators. Some preliminary steps in this direction, inspired by the Social Networks Analysis, were presented, although it is necessary to do a more extensive experimental validation. The main difficulty is naturally the determination of the "level of health" of the relationships and the worth corresponding to each asset. In order to collect and record those values without being intrusive in the network member's 'life' requires further research and development. It is also important to rank the indicators according to their practical usefulness. Such ranking should encompass the vision and strategy defined for the collaborative network.

The proposed model, although simplistic, has the advantage of providing a visual/graphical representation which is easy to understand. The development of a system to monitor and keep track of the changes over time is particularly useful here.

Acknowledgments. This work was supported in part by the FCT-MCTES "Fundação para a Ciência e Tecnologia" (CTS multiannual funding) through the PIDDAC Program funds", and the European Commission through GloNet project.

\section{References}

1. Beckett, R.C.: Perceptions of value that sustain collaborative networks. In: CamarinhaMatos, L.M., Afsarmanesh, H., Ortiz, A. (eds.) Collaborative Networks and Their Breeding Enviroments. Springer, Heidelberg (2005)

2. Afsarmanesh, H., Marik, V., Camarinha-Matos, L.M.: Challenges of collaborative networks in Europe. In: Camarinha-Matos, L.M., Afsarmanesh, H. (eds.) Collaborative Networked Organizations: A Research Agenda for Emerging Business Models. Kluwer Academic Publishers, Dordrecht (2004) 
3. Tenera, A., Abreu, A.: A TOC perspective to improve the management of collaborative networks. In: Camarinha-Matos, L.M., Picard, W. (eds.) Pervasive Collaborative Networks, pp. 167-176. Springer, Boston (2008)

4. Camarinha-Matos, L.M., Abreu, A.: A contribution to understand collaboration benefits. In: Camarinha-Matos, L.M. (ed.) Emerging Solutions for Future Manufacturing Systems. Springer, Heidelberg (2004)

5. Bankston, C.L., Zhou, M.: Social Capital as a Process: The Meanings and Problems of a Theoretical Metaphor? Sociological Inquiry 72(2), 285-317 (2002)

6. Adler, P.S., Kwon, S.-W.: Social Capital: Prospects for a new concept. The Academy of Management Review 27, 17-40 (2002)

7. Stone, W.: Measuring social capital: Towards a theoretically informed measurement framework for researching social capital in family and community life. Family Matters Autumn 38 (2001)

8. Francis, J., Mukherji, A., Mukherji, J.: Examining relational and resource influences on the performance of border region SMEs. International Business Review 18(4), 331-343 (2009)

9. Bourdieu, P.: The Forms of Capital. In: Richardson, J.G. (ed.) Handbook of Theory and Research for Sociology of Education, pp. 241-258. Greenwood Press, New York (1986)

10. Portes, A.: Social Capital its origins and applications in modern sociology. Annual Review of Sociology 24, 1-25 (1998)

11. Nahaiet, J., Ghoshal, S.: Social Capital, Intellectual Capital, and the organizational advantage. Academy of Management Review 23(2), 242-266 (1998)

12. Fukuyama, F.: Social Capital and the modern capitalist economy: Creating a high trust worplace. Stern Business Magazine (1997)

13. Camarinha-Matos, L.M., Abreu, A.: Performance indicators based on colaborative benefits. In: Camarinha-Matos, L.M., Afsarmanesh, H., Ortiz, A. (eds.) Collaborative Networks and Their Breeding Enviroments. Springer, Heidelberg (2005)

14. Robison, L.J., Schimid, A., Siles, M.E.: Is social capital really capital? Review of Social Economy 60, 1-24 (2002)

15. Gant, J., Ichniowski, C., Shaw, K.: Social capital and organisational change in high involvement and traditional work organisations. Journal of Economics and Management 11, 289-328 (2002)

16. Abreu, A., Camarinha-Matos, L.M.: Understanding Social Capital in Collaborative Networks. In: Bas, Á.O., Franco, R.D., Gasquet, P.G. (eds.) BASYS 2010. IFIP AICT, vol. 322, pp. 109-118. Springer, Heidelberg (2010) 